\title{
HOW DO PLANTS RESPOND TO PATCH AREA AND ITS DISTRIBUTION PATTERN IN HORQIN SAND LAND, CHINA
}

\author{
WU, J. ${ }^{1,2}-$ HoU, X. Z. ${ }^{1}-$ XU, C. L. ${ }^{3}-$ LIU, Z. M. ${ }^{2 *}$ \\ ${ }^{1}$ Liaoning Ecological Engineering Vocational College, Shenyang 110001, P R China \\ ${ }^{2}$ Institute of Applied Ecology, Chinese Academy of Sciences, Shenyang 110016, P R China \\ ${ }^{3}$ Experimental Forest Farm of Liaoning province, Fushun 113300, P R China \\ ${ }^{*}$ Corresponding author \\ e-mail:0227wujing@163.com
}

(Received 30 $0^{\text {th }}$ Sep 2018; accepted $29^{\text {th }}$ Nov 2018)

\begin{abstract}
To elucidate the plant response to habitat fragmentation, 18 interdune lowlands with different sizes in active sand dunes of Horqin Sand Land were selected, and the interdune lowland was considered as fragmented habitat patch. In our study, the effect of patch size on plant distribution pattern was explored and different protocols of species diversity conservation were proposed. Our results showed different plant sensitivities to habitat fragmentation: type I, species are restricted by patch area and distributed regularly in fragments; type II, species are not restricted by patch area, and their distribution is irregular in fragments; type III, species mainly distributed in large fragments; type IV, species mainly distributed in small fragments; type V, species mainly distributed in middle-sized fragments. Exploring the effects of fragmentation habitat size on plant species diversity and its distribution pattern will provide theoretical basis for plant diversity conservation in semi-arid sand dunes.
\end{abstract}

Keywords: biodiversity, habitat loss, habitat isolation, patch, landscape

\section{Introduction}

Habitat fragmentation has been considered as one of the major threats to biodiversity (Brunet et al., 2011; Wu et al., 2013; Murphy and Romanuk 2014; Matthews et al., 2014; Ducatez and Shine, 2017). Fragmentation processes often result in "patchy" habitat segments, called patchy habitat. As the degree of fragmentation increases, the original patch is isolated from the highly altered retrogressive landscape and gradually recedes and eventually develops into a biogeographic "habitat islands", producing a range of ecological or biological effects at different levels of population, community, ecosystem and even landscape.

The size, environmental heterogeneity and marginal effects of habitat patches have important effects on species richness and abundance in patches (Benedick et al., 2006; Santos et al., 2008; Leal et al., 2012; Fahrig et al., 2015). Different species have different sensitivity, adaptability and tolerance to landscape fragmentation (Haila, 2002; Hill et al., 2003; Swihart et al., 2003; Kolb et al., 2005; Hudson et al., 2017). The influence of habitat patches such as Qiandao Lake and Three Gorges Reservoir on plant diversity has been reported in China (Ding, 2005). Many studies have focused on the real islands in geography (Halley et al., 2014; Phillips et al., 2018), but less attention has been paid to the ecological effects of habitat patches in the broad sense of biogeography and ecology. As a relatively independent vegetation unit in sand dune ecosystem, the interdune lowlands have unique patch properties in sand dune landscape, which can be regarded as "fragmented habitat islands" in sand dune ecosystem, and play an important role in determining plant diversity and distribution pattern of sand dune ecosystem. 
However, the impact of fragmented patch area in the sand dune ecosystems of semi-arid regions (i.e., interdune lowlands) on plant diversity and island accumulation has not been reported.

Therefore, we investigated the plant diversity of interdune lowlands in the active dune ecosystem of the Horqin Sandy land, and conducted regression analysis on the relationship between the relative frequency and abundance of typical species and fragmented island area. This study is aiming to explore the plant diversity protection scheme applicable to different ecological groups and reveal the processes and mechanisms of the impacts of the habitat island on the plant diversity. This study can provide a theoretical basis for biodiversity protection and guides the practice of biodiversity protection in semi-arid areas.

\section{Material and Methods}

\section{Study site}

The study site is located at Wulanaodu region $\left(42^{\circ} 47^{\prime}-43^{\circ} 25^{\prime} \mathrm{N}, 118^{\circ} 38^{\prime}-120^{\circ} 43^{\prime} \mathrm{E}\right.$, $480 \mathrm{~m}$ a.s.1.), eastern Inner Mongolia, China (Figure 1). The region has a semi-arid climate. The annual average temperature is $6.3^{\circ} \mathrm{C}$. The annual average rainfall is ca. 340 $\mathrm{mm}$, most of which is received during June to September. The windy season is from March to May. The growing season starts in late April and ends in late September.

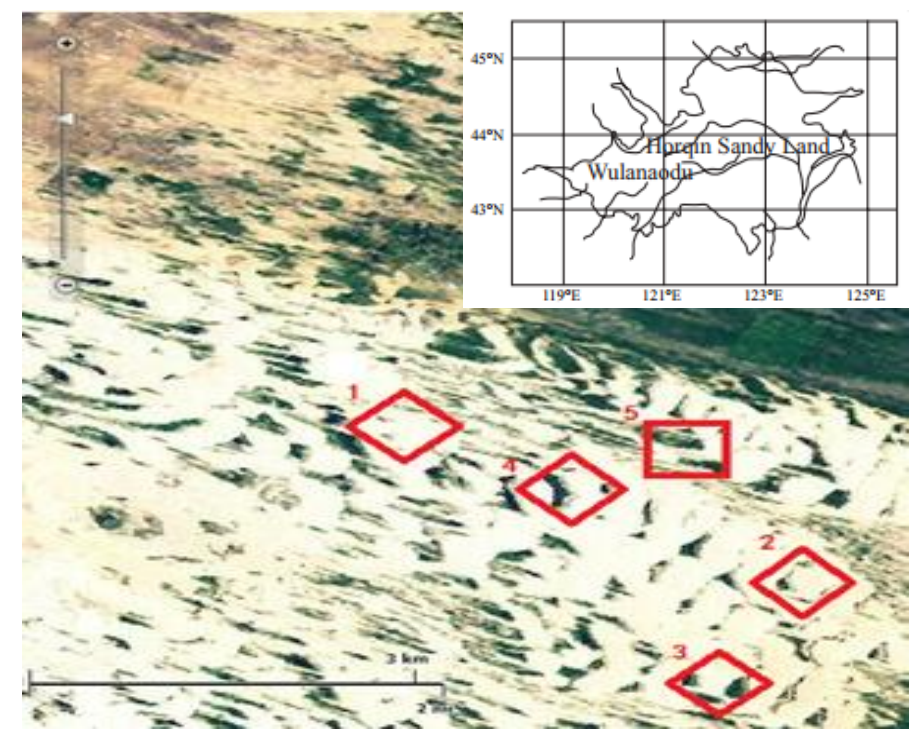

Figure 1. Location map and five sampling sites in Horqin sandy land

The active sand dune areas, 15-35 $\mathrm{m}$ in height, are advancing at a speed of ca. 6-7 m year-1, and, following the aforementioned fencing since the 1980s, are permanently closed off from the natural grassland (>600 ha). The natural grassland and the active sand dunes experience the same climatic conditions, i.e. similar rainfall, temperature, humidity etc. The vegetation before the intense grazing period was dominated by perennial grasses, such as Phragmites communis and Calamagrostis epigeios, whereas after the onset of grazing pasammophilous species, such as Artemisia wudanica and Agriophyllum squarrosum, became more established. 


\section{Experimental procedures}

We selected 18 interdune lowlands ranging in size from 0.10 to $5.64 \mathrm{hm}^{2}$ in 2012 (Table 1) (Liu et al., 2003). We used grid sampling at a resolution of $10 \times 10 \mathrm{~m}$. We established transects divided into $10-\mathrm{m}$ intervals in each plot, all running in the vertical direction of the prevailing wind, and then selected $1 \times 1 \mathrm{~m}$ quadrats, 10 -m-spaced, along each transect (Wu et al., 2016). The species richness and abundance in the sample were recorded. For bunchgrasses (e.g. C. squarrosa), we counted the number of clusters to obtain the abundance, whereas for clonal species (e.g. S. gordejevii and P. communis) we counted the number of ramets, and for discrete species (e.g. A. squarrosum) the number of individuals were counted. The frequency of each species was determined within each plot.

Table 1. Basic information of 18 selected interdune lowlands

\begin{tabular}{c|c|c|c}
\hline Plot number & $\begin{array}{c}\text { Geographical coordinates of the center of the } \\
\text { interdune lowland }\end{array}$ & $\begin{array}{c}\text { Size } \\
\left(\mathbf{h m}^{\mathbf{2}}\right)\end{array}$ & $\begin{array}{c}\text { Dam Height } \\
(\mathbf{m})\end{array}$ \\
\hline 1 & $42^{\circ} 59.900 \mathrm{~N}, 119^{\circ} 38.009 \mathrm{E}$ & 0.05 & 25 \\
2 & $42^{\circ} 59.367 \mathrm{~N}, 119^{\circ} 38.789 \mathrm{E}$ & 0.27 & 28.5 \\
3 & $42^{\circ} 58.089 \mathrm{~N}, 119^{\circ} 38.169 \mathrm{E}$ & 0.30 & 25.5 \\
4 & $42^{\circ} 58.170 \mathrm{~N}, 119^{\circ} 37.886 \mathrm{E}$ & 0.32 & 25 \\
5 & $43^{\circ} 00.964 \mathrm{~N}, 119^{\circ} 38.887 \mathrm{E}$ & 0.60 & 24 \\
6 & $42^{\circ} 59.789 \mathrm{~N}, 119^{\circ} 37.236 \mathrm{E}$ & 0.66 & 25 \\
7 & $42^{\circ} 59.767 \mathrm{~N}, 119^{\circ} 37.709 \mathrm{E}$ & 0.67 & 22.5 \\
8 & $42^{\circ} 59.640 \mathrm{~N}, 119^{\circ} 37.886 \mathrm{E}$ & 1.00 & 25 \\
9 & $42^{\circ} 59.805 \mathrm{~N}, 119^{\circ} 37.964 \mathrm{E}$ & 1.35 & 24.5 \\
10 & $43^{\circ} 00.001 \mathrm{~N}, 119^{\circ} 37.870 \mathrm{E}$ & 2.27 & 23 \\
11 & $42^{\circ} 59.862 \mathrm{~N}, 119^{\circ} 37.974 \mathrm{E}$ & 2.94 & 19 \\
12 & $42^{\circ} 59.958 \mathrm{~N}, 119^{\circ} 37.844 \mathrm{E}$ & 3.22 & 23 \\
13 & $42^{\circ} 59.442 \mathrm{~N}, 119^{\circ} 38.749 \mathrm{E}$ & 4.35 & 26.5 \\
14 & $43^{\circ} 00.336 \mathrm{~N}, 119^{\circ} 37.609 \mathrm{E}$ & 5.01 & 25 \\
15 & $42^{\circ} 00.498 \mathrm{~N}, 119^{\circ} 37.154 \mathrm{E}$ & 5.25 & 24.5 \\
16 & $42^{\circ} 00.598 \mathrm{~N}, 119^{\circ} 38.504 \mathrm{E}$ & 6.19 & 26 \\
17 & $42^{\circ} 00.156 \mathrm{~N}, 119^{\circ} 38.454 \mathrm{E}$ & 6.84 & 22 \\
18 & $42^{\circ} 00.453 \mathrm{~N}, 119^{\circ} 37.231 \mathrm{E}$ & 11.3 & 24.5 \\
\hline
\end{tabular}

\section{Species diversity measure}

- Species abundance: number of species within a community.

- Frequency of a species $(\%)=$ occurrence of the certain species/number of total samples.

- Abundance of a species $(\%)=$ total plants of certain species/ total plants of total species.

\section{Classification of typical plant responses to habitat fragmentation}

Based on the differences of typical plant responses to the habitat area, plants were divided into the five categories (Table 2).

\section{Data analysis}

All the statistic analysis was conducted in SPSS software. Model selection was based on maximum $\mathrm{R}^{2}$, and residual analysis showed that the model fit was adequate. 
Statistical significance was determined at $\mathrm{P}=0.05$. We analyzed the relationships between patch area and frequency and relative abundance for 6 type's species.

Table 2. Classification of typical plant responses to habitat fragmentation

\begin{tabular}{c|c|c}
\hline Type & Relationship & Distribution \\
\hline I & Significant & Regular \\
\hline II & No significant & Irregular \\
\hline III & Significant & Mainly distributed in large fragments \\
\hline IV & No significant & Mainly distributed in small fragments \\
\hline V & No significant & Mainly distributed in middle-sized fragments \\
\hline
\end{tabular}

\section{Results}

\section{Species composition}

According to the data of 18 interdune lowlands, there are 114 species belonging to 36 families in the patch habitat of horqin Sandy land. Among them, 25 species belong to Compositae, 13 species belong to Graminae, 11 species belong to Leguminosae, 6 species belong to Cyperaceae, 7 species belong to Chenopodiaceae, and the remaining 57 species belong to 31 families. Among them, 10 species is Psammophytes, 76 species are meadows plants and 22 species are steppes (Table 3 ).

Table 3. Species list in the 18 selected patchy habitats

\begin{tabular}{|c|c|c|c|c|c|}
\hline Number & species & General & Ecological group & Life form & Frequency \\
\hline 1 & Artemisia halodendron & Compositae & $\mathrm{P}$ & SS & 0.99 \\
\hline 2 & Artemisia wudanica & & $\mathrm{P}$ & SS & 1.36 \\
\hline 3 & Artemisia frigida & & $\mathrm{P}$ & SS & 1.24 \\
\hline 4 & Inula salsoloides & & $\mathrm{P}$ & PH & 10.7 \\
\hline 5 & Artemisia gmelinii & & LMS & SS & 0.33 \\
\hline 6 & Artemisia lavandulaefolia & & LMS & PH & 23.5 \\
\hline 7 & Erigeron acer & & LMS & BH & 0.06 \\
\hline 8 & Eupatorium lindleyanum & & LMS & PH & 0.07 \\
\hline 9 & Hypochoeris grandiflora & & LMS & PH & 0.03 \\
\hline 10 & Inula britannica & & LMS & PH & 8.78 \\
\hline 11 & Lactuca indica & & LMS & BH & 1.06 \\
\hline 12 & Lactuca tatarica & & LMS & PH & 5.70 \\
\hline 13 & Leibnitzia anandria & & LMS & PH & 6.89 \\
\hline 14 & Taraxacum mongolicum & & LMS & $\mathrm{PH}$ & 16.7 \\
\hline 15 & Taraxacum borealisinense & & LMS & PH & 3.45 \\
\hline 16 & Carduus nutans & & LMS & $\mathrm{BH}$ & 0.02 \\
\hline 17 & Cirsium segetum & & LMS & PH & 0.46 \\
\hline 18 & Ixeris chinensis & & LMS & PH & 34.1 \\
\hline 19 & Scorzonera capito & & LMS & PH & 0.05 \\
\hline 20 & Senecio jacobacea & & LMS & $\mathrm{PH}$ & 0.42 \\
\hline 21 & Sonchus brachyotus & & LMS & $\mathrm{PH}$ & 10.4 \\
\hline 22 & Serratula cardunculus & & LMS & PH & 0.04 \\
\hline 23 & Xanthium sibiricum & & LMS & $\mathrm{AH}$ & 0.07 \\
\hline
\end{tabular}




\begin{tabular}{|c|c|c|c|c|c|}
\hline Number & species & General & Ecological group & Life form & Frequency \\
\hline 24 & Heteropappusaltaicus & \multirow{3}{*}{ Chenopodiaceae } & STS & $\mathrm{PH}$ & 0.18 \\
\hline 25 & Agriophyllum squarrosum & & $\mathrm{P}$ & $\mathrm{AH}$ & 0.34 \\
\hline 26 & Corispermum candelabrum & & $\mathrm{P}$ & $\mathrm{AH}$ & 5.77 \\
\hline 27 & Salix gordejevii & Salicaceae & $\mathrm{P}$ & $\mathrm{S}$ & 34.5 \\
\hline 28 & Caragana microphylla & Leguminosae & $\mathrm{P}$ & $\mathrm{S}$ & 1.56 \\
\hline 29 & Hedysarum fruticosum & \multirow{13}{*}{ Gramineae } & $\mathrm{P}$ & SS & 3.76 \\
\hline 30 & Agrostis clavata & & LMS & $\mathrm{PH}$ & 16.8 \\
\hline 31 & Arthraxon hispidus & & LMS & $\mathrm{AH}$ & 9.87 \\
\hline 32 & Calamagrostis epigeios & & LMS & $\mathrm{PH}$ & 46.6 \\
\hline 33 & Pennisetum alopecuroides & & LMS & $\mathrm{PH}$ & 1.31 \\
\hline 34 & Phragmites communis & & LMS & $\mathrm{PH}$ & 60.4 \\
\hline 35 & Miscanthussacchariflorus & & LMS & $\mathrm{PH}$ & 15.6 \\
\hline 36 & Echinochloa frumentacea & & LMS & $\mathrm{PH}$ & 0.31 \\
\hline 37 & Septoria mougeotii & & LMS & $\mathrm{PH}$ & 0.02 \\
\hline 38 & Chloris virgata & & LMS & $\mathrm{AH}$ & 10.8 \\
\hline 39 & Eragrostis pilosa & & LMS & $\mathrm{AH}$ & 30.2 \\
\hline 40 & Setaria viridis & & LMS & $\mathrm{AH}$ & 0.98 \\
\hline 41 & Pennisetum centrasiaticum & & LMS & $\mathrm{PH}$ & 1.67 \\
\hline 42 & Astragalus adsurgens & \multirow[t]{9}{*}{ Leguminosae } & LMS & $\mathrm{PH}$ & 0.45 \\
\hline 43 & Glycine soja & & LMS & $\mathrm{AH}$ & 3.06 \\
\hline 44 & Kummerowia striata & & LMS & $\mathrm{PH}$ & 2.64 \\
\hline 45 & Melilotus suaveolens & & LMS & $\mathrm{ABH}$ & 0.67 \\
\hline 46 & Trigonella korshinskyi & & LMS & $\mathrm{AH}$ & 0.01 \\
\hline 47 & Vicia amoena & & LMS & $\mathrm{PH}$ & 0.34 \\
\hline 48 & Swainsonia salsula & & LMS & SS & 1.78 \\
\hline 49 & Thermopsis lanceolata & & LMS & $\mathrm{PH}$ & 1.83 \\
\hline 50 & Radix Glycyrrhizae & & STS & $\mathrm{PH}$ & 0.65 \\
\hline 51 & Bolboschoenus compacts & \multirow[t]{6}{*}{ Cyperaceae } & LMS & $\mathrm{PH}$ & 5.91 \\
\hline 52 & Bolboschoenus planiculmis & & LMS & $\mathrm{PH}$ & 0.37 \\
\hline 53 & Carex caespitosa & & LMS & $\mathrm{PH}$ & 10.6 \\
\hline 54 & Carex duriuscula & & LMS & $\mathrm{PH}$ & 12.3 \\
\hline 55 & Heleochalis intersita & & LMS & $\mathrm{PH}$ & 0.26 \\
\hline 56 & Scirpus tabernaemontani & & LMS & $\mathrm{PH}$ & 0.02 \\
\hline 57 & Populus spp. & \multirow[t]{3}{*}{ Salicaceae } & LMS & S & 5.76 \\
\hline 58 & Salix microstachya & & LMS & $\mathrm{S}$ & 31.5 \\
\hline 59 & Salix mongolica & & LMS & S & 0.87 \\
\hline 60 & Alisma orientale & \multirow[t]{2}{*}{ Alismataceae } & LMS & $\mathrm{PH}$ & 0.04 \\
\hline 61 & Sagittaria trifolia & & LMS & $\mathrm{PH}$ & 0.05 \\
\hline 62 & Chenopodium acuminatum & \multirow[t]{5}{*}{ Chenopodiaceae } & LMS & $\mathrm{AH}$ & 0.04 \\
\hline 63 & Chenopodium glaucum & & LMS & $\mathrm{AH}$ & 3.67 \\
\hline 64 & Bassia dasyphylla & & STS & $\mathrm{AH}$ & 0.34 \\
\hline 65 & Chenopodium aristatum & & STS & $\mathrm{AH}$ & 0.22 \\
\hline 66 & Salsola ruthenica & & STS & $\mathrm{AH}$ & 0.12 \\
\hline 67 & Polygonum hydropiper & \multirow[t]{3}{*}{ Polyonaceae } & LMS & $\mathrm{PH}$ & 0.02 \\
\hline 68 & Polygonum lapathifolium & & LMS & $\mathrm{AH}$ & 0.01 \\
\hline 69 & Polygonum thunbergii & & LMS & $\mathrm{AH}$ & 0.01 \\
\hline
\end{tabular}




\begin{tabular}{|c|c|c|c|c|c|}
\hline Number & species & General & Ecological group & Life form & Frequency \\
\hline 70 & Polygonum laxmanni & & $\mathrm{P}$ & $\mathrm{PH}$ & 0.01 \\
\hline 71 & Equisetum ramosissimum & Equisetaceae & LMS & PH & 0.02 \\
\hline 72 & Eguisetum sylvalicum & & LMS & PH & 0.02 \\
\hline 73 & Euphorbia humifusa & Euphorbiaceae & LMS & $\mathrm{AH}$ & 0.02 \\
\hline 74 & Gentiana squarrosa & Gentianaceae & LMS & $\mathrm{PH}$ & 0.02 \\
\hline 75 & Plantago depressa & Plantaginaceae & LMS & $\mathrm{PH}$ & 3.09 \\
\hline 76 & Glaux maritima & Primulaceae & LMS & $\mathrm{PH}$ & 0.05 \\
\hline 77 & Halerpestes cymbalaria & Ranumculaceae & LMS & $\mathrm{PH}$ & 5.93 \\
\hline 78 & Potentilla discolor & Rosaceae & LMS & PH & 1.32 \\
\hline 79 & Potentillae Chinensis & & LMS & $\mathrm{PH}$ & 1.02 \\
\hline 80 & Potentilla supina & & LMS & $\mathrm{PH}$ & 0.67 \\
\hline 81 & Potentilla anserina & & LMS & $\mathrm{PH}$ & 0.66 \\
\hline 82 & Typha minima & Typhaceae & LMS & PH & 1.33 \\
\hline 83 & Artemisia laciniata & Compositae & STS & PH & 1.78 \\
\hline 84 & Artemisia scoparia & & STS & $\mathrm{ABH}$ & 3.65 \\
\hline 85 & Artemisia sieversiana & & STS & $\mathrm{ABH}$ & 1.34 \\
\hline 86 & Heteropappus altaicus & & STS & $\mathrm{PH}$ & 0.34 \\
\hline 87 & Lespedeza davurica & Leguminosae & STS & SS & 10.9 \\
\hline 88 & Oxytropis ramosissima & & STS & $\mathrm{PH}$ & 0.02 \\
\hline 89 & Sophora flavescens & & STS & PH & 1.98 \\
\hline 90 & Cynanchum sibiricum & Asclepiadaceae & STS & $\mathrm{PH}$ & 0.31 \\
\hline 91 & C. chinense & & STS & PH & 0.01 \\
\hline 92 & Cleistogenes squarrosa & Gramineae & STS & $\mathrm{PH}$ & 6.81 \\
\hline 93 & Galium verum & Rubiaceae & STS & $\mathrm{PH}$ & 0.28 \\
\hline 94 & Rubiaschumahhiaha & & $\mathrm{P}$ & $\mathrm{PH}$ & 0.01 \\
\hline 95 & Ulmus pumila & Ulmaceae & STS & S & 0.05 \\
\hline 96 & Linaria vulgaris & Scrophulariaceae & LMS & $\mathrm{PH}$ & 0.01 \\
\hline 97 & Portulaca oleracea & Portulacaceae & STS & $\mathrm{AH}$ & 0.05 \\
\hline 98 & Spiked Loosestrlfe & Lythraceae & LMS & $\mathrm{PH}$ & 0.01 \\
\hline 99 & Lythrum virgatum & & LMS & $\mathrm{PH}$ & 0.01 \\
\hline 100 & Erodium stephanianum & Geraniaceae & LMS & $\mathrm{PH}$ & 0.01 \\
\hline 101 & Allium odorum & Liliaceae & LMS & $\mathrm{PH}$ & 0.01 \\
\hline 102 & Asparagus brachyphyllus & & LMS & $\mathrm{PH}$ & 0.01 \\
\hline 103 & Asparagua dahuricus & & LMS & $\mathrm{PH}$ & 0.01 \\
\hline 104 & Viola philippica & Violaceae & LMS & $\mathrm{PH}$ & 0.01 \\
\hline 105 & Viola prionantha & & LMS & $\mathrm{PH}$ & 0.01 \\
\hline 106 & Tragus bertesonianus & Rutaceae & STS & $\mathrm{PH}$ & 0.01 \\
\hline 107 & Lappula echinata & Boraginaceae & STS & $\mathrm{ABH}$ & 0.01 \\
\hline 108 & Radix Arnebiae & & STS & $\mathrm{PH}$ & 0.01 \\
\hline 109 & Scutellaria baicalensis & Labiatae & STS & $\mathrm{PH}$ & 0.01 \\
\hline 110 & Tirbulus terrestris & Zygophyllaceae & LMS & $\mathrm{AH}$ & 0.01 \\
\hline 111 & Saposhnikovia divaricata & Umbelliferae & STS & $\mathrm{PH}$ & 0.01 \\
\hline 112 & Silene jenisseensis & Caryophyllaceae & STS & $\mathrm{PH}$ & 0.02 \\
\hline 113 & Cuscuta chinensis & Convolvulaceae & STS & $\mathrm{AH}$ & 0.01 \\
\hline 114 & Betula platyphylla & Betula & LMS & $\mathrm{S}$ & 0.01 \\
\hline
\end{tabular}




\section{The responses of typical plants to fragmented patch area}

Type I (species is restricted by patch area and distributed regularly in fragments)

The frequency and relative abundance of Artemisia wudanica, Phragmites communis decreased logarithmically. The frequency and relative abundance of Lespedeza davurica showed a change of binomial function with the increase of the area of the fragmented habitat, when the area of plaque is around $2 \mathrm{hm}^{2}$, its frequency is lowest, and its relative abundance tends to increase with patch area (Figure 2).
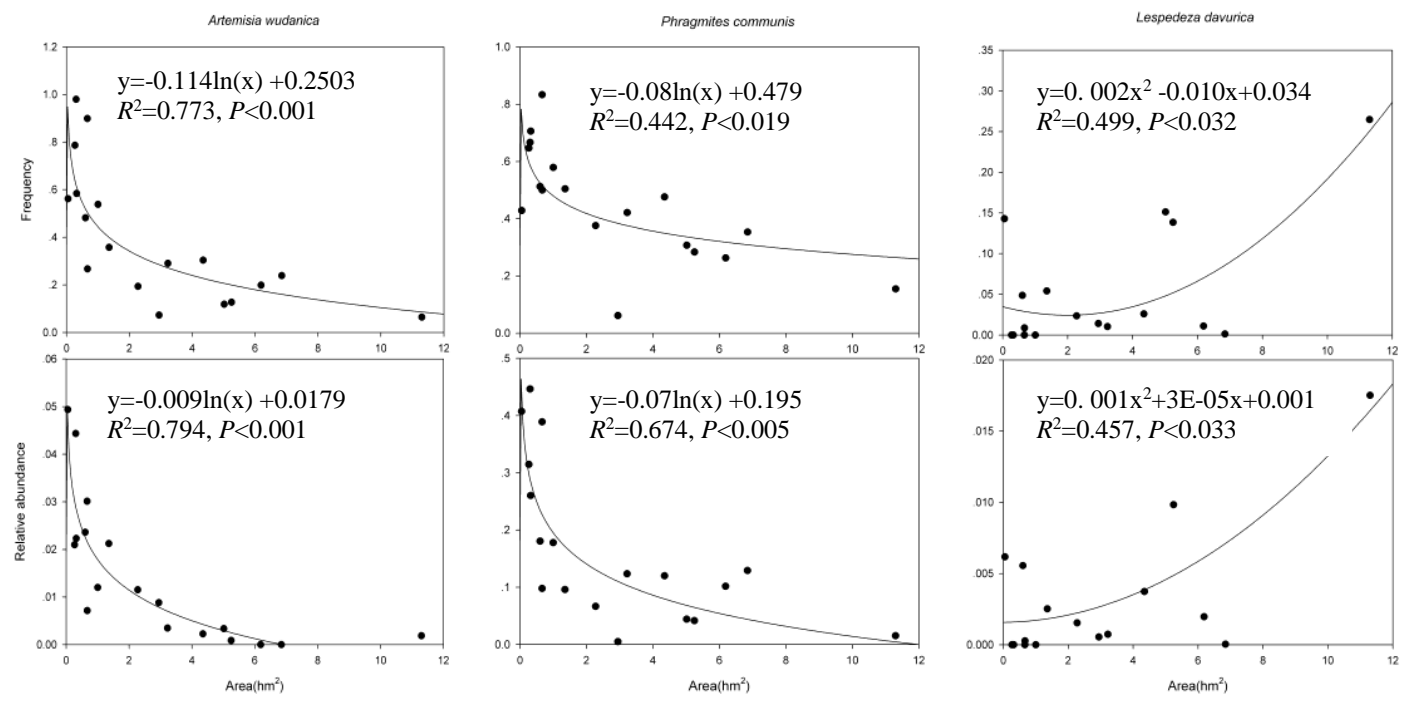

Figure 2. Changes in the frequency and abundance of Artemisia wudanica, Phragmites communis, Lespedeza davurica with increasing interdune lowland size

Type II (species is not restricted by patch area, and their distribution is irregular in fragments)

There was no significant change in the frequency and relative abundance of Salix gordejevii with the increase of plaque habitat area. Salix gordejevii appeared in different interdune lowlands, and the relative abundance of Salix gordejevii decreased with the increase of patch area (Figure 3).

\section{Type III (species mainly distributed in large fragments)}

The frequency and relative abundance of Eragrostis pilosai increased significantly with the increase of patch area, that is, the population size and distribution of Eragrostis pilosai declined sharply (Figure 4).

\section{Type IV (species mainly distributed in small fragments)}

The frequency and relative abundance of Vicia amoena showed no significant change with the increase of patch area. Vicia amoena is more frequent in small and mediumsized interdune lowlands; the population size of Vicia amoena varies little with increased habitat fragmentation (Figure 5). 


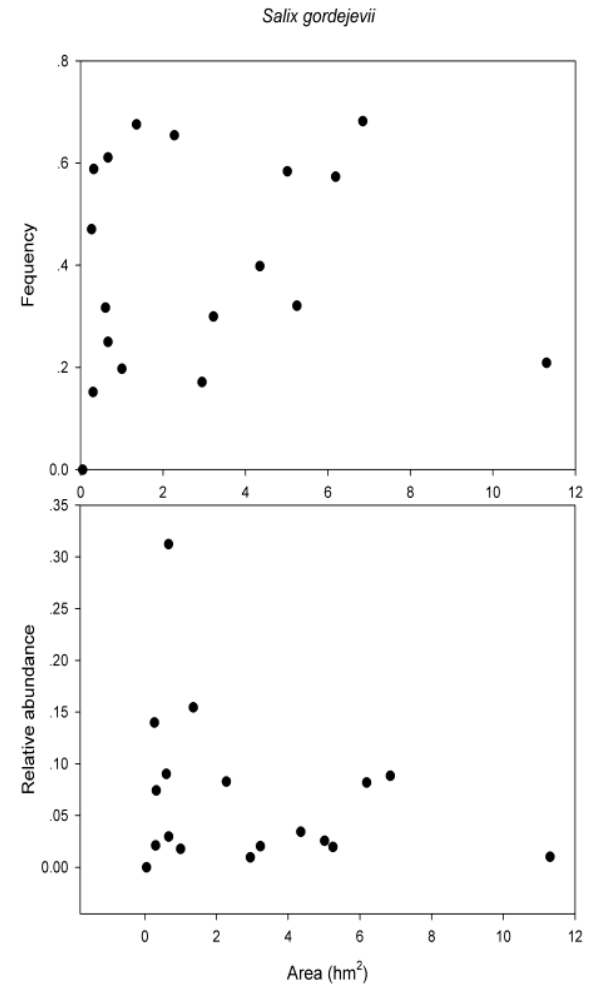

Figure 3. Changes in the frequency and relative abundance of Salix gordejevii population with interdune lowland area

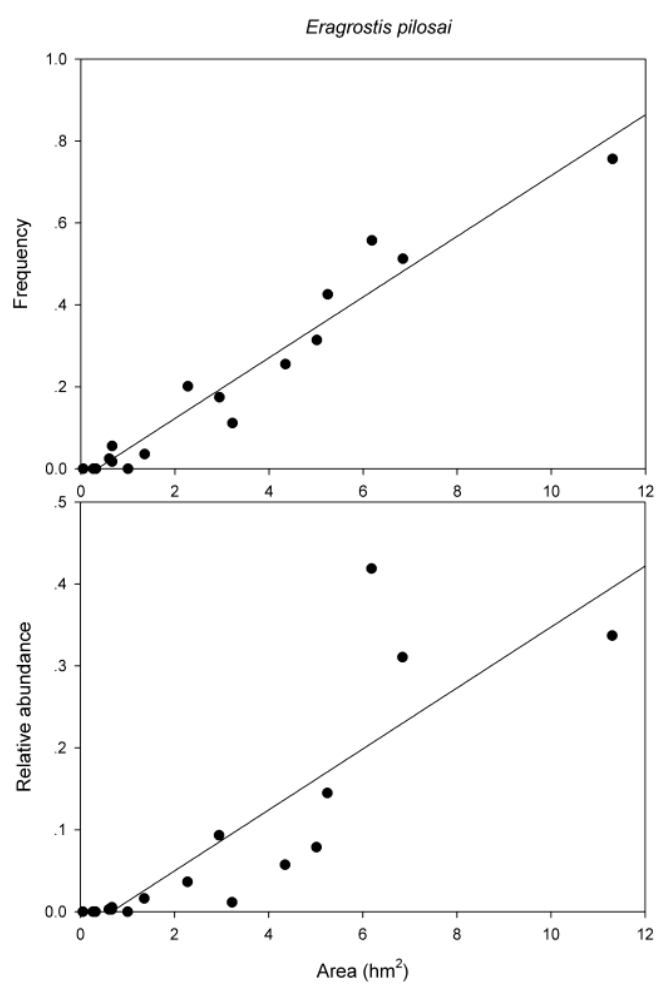

Figure 4. Changes in the frequency and relative abundance of Eragrostis pilosai population with interdune lowland area

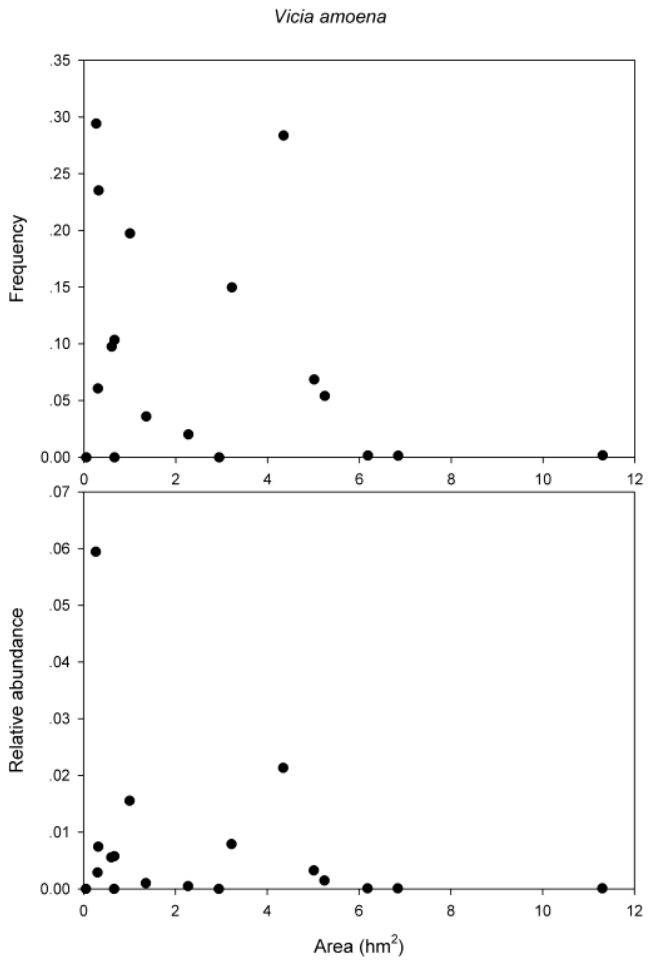

Figure 5. Changes in the frequency and relative abundance of Vicia amoena population with interdune lowland area 


\section{Type $V$ (species mainly distributed in middle-sized fragments)}

The frequency and relative abundance of Chenopodium aristatum showed no significant change with the increase of patch area, the frequency of Chenopodium aristatum was higher in medium size patch and lower in small and large size patch. The population size of Chenopodium aristatum had no significant change with the increase of habitat fragmentation. There was no significant change in the frequency and relative abundance of Sophora miltiorrhiza with the increase of patch area, and the size of population was not significant change with the increase of habitat fragmentation (Figure б).
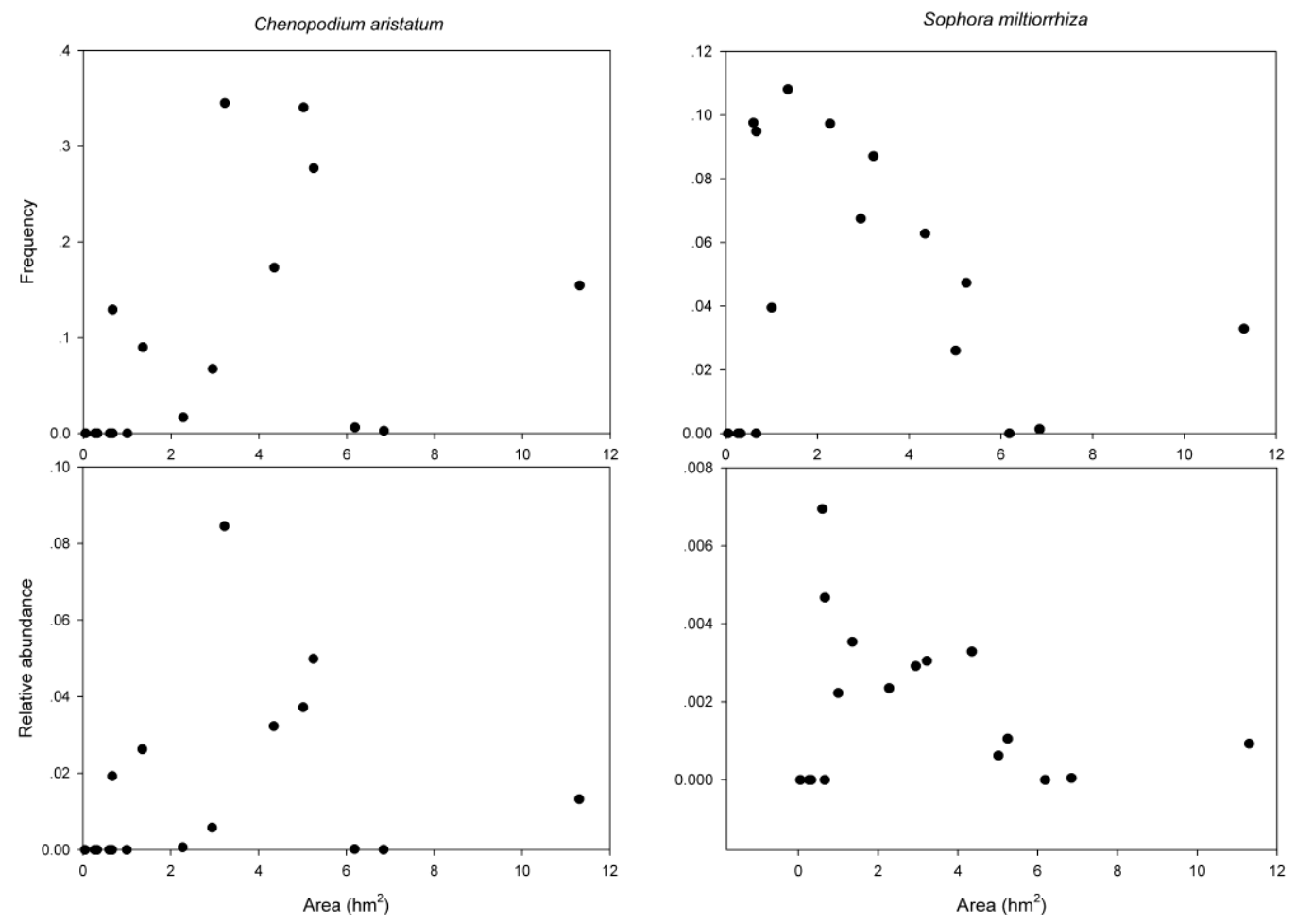

Figure 6. Change in the frequency and relative abundance of Chenopodium aristatum and Sophora miltiorrhiza with interdune lowland area

\section{Discussion}

Contrary to the existing view that species frequency show a negative trend with decreasing fragment area (Hill and Curran, 2003; Echeverría et al., 2007; Kornera and Jeltschb, 2008), our results showed that some species responded positively to habitat fragmentation and the species tolerance to habitat fragmentation was different. The plant-environmental feedback process in the dune system has a significant effect on plant growth and reproduction (Hambäck et al., 2007; Giladi et al., 2014; Winfree et al., 2015). The feedback process of Artemisia wudanica to wind erosion is as follows: After Artemisia wudanica is blown by the wind, the plant will fall down at a certain wind erosion depth, and the sand blocking area will increase accordingly. The microenvironment of the buried parts of the plants has changed. For example, 1) the soil volume has increased and the soil water content has increased; 2) mycorrhizal fungus activity capacity increased; 3) in the effective use of resources increased in the soil. 
These changes have created favorable conditions for the adventitious roots on the sandy branches. In the case of a large number of adventitious roots, the growth of the plant increases, and the ability to block sand increases.

Reeds can appear in meadow grasslands and in the interdune lowlands. On the one hand, they belong to meadows, and on the other hand, they have the ability to adapt to wind sand. Previous studies have concluded that reeds can quickly invade and settle in habitats with intense sand activity due to its strong cloning and reproduction ability, (Liu et al., 2006; Liu et al., 2008). Therefore, in the broken patches of mobile dunes, especially in small areas with intense sand activity (Ma et al., 2010; Zobel et al., 2010; $\mathrm{Wu}$ et al., 2013), reeds show the ability to adapt to sandstorm interference (Liu et al., 2007). Reeds can be rapidly expanded from lowland to windward slopes through Rhizome extension and asexual strains. As pioneers, they create suitable habitat conditions for other species to invade, drive new vegetation succession in transition zones, and reduce wind and sand fluidity.

Lespedeza davurica has a persistent soil seed bank and can also ensure its population development under strong interference, while playing an important role in maintaining community diversity and system stability ( $\mathrm{Li}$ et al., 2006). Lespedeza davurica population can expand the adjacent space by increasing the number of branches. The high-density population of Lespedeza davurica expands the plant elevation space in the form of lateral branches, that is, transverse space. The low-density population of Lespedeza davurica occupied the longitudinal space by increasing its branches, gradually occupied the horizontal space (Li, 2005).

\section{Conclusions}

In the practice of species diversity conservation, programmers should be tailored to the sensitivity of the species to habitat fragmentation. For example, with the increase in the area of patches, the frequency and relative diversity of Artemisia wudanica, Phragmites communis, and Vicia amoena are all reduced. Therefore, when protecting Artemisia wudanica, Phragmites communis, and Vicia amoena, the focus should be on protecting small islands. The frequency and relative abundance of Lespedeza davurica increase with the increase of patch area. Therefore, when protecting Lespedeza davurica, we should focus on a large area of islands; the frequency and relative abundance of Chenopodium aristatum and Sophora flavescens are higher in the middle area islands, therefore, when protecting Chenopodium aristatum and Sophora flavescens, the middle area islands should be protected.

Acknowledgments. We thank Jianqiang Qian and Yongming Luo for field assistance. The study was financially supported by the National Natural Science Youth Foundation of China (31600443) and the Liaoning Natural Science Foundation (201800170) .

\section{REFERENCES}

[1] Benedick, S., Hill, J. K., Mustaffa, N., Chey, V. K., Maryati, M., Searle, J. B., Schilthuizen, M., Hamer, K. C. (2006): Impacts of rain forest fragmentation on butterflies in northern Borneo: Species richness, turnover and the value of small fragments. - J Appl Ecol 43: 967-977. 
[2] Brunet, J., Valtinat, K., Mayr, L. M., Felton, A., Lindbladh, M., Bruu, H. H. (2011): Understory succession in post-agricultural oak forests: habitat fragmentation affects forest specialists and generalists differently. - For. Ecol. Manage. 262: 1863-1871.

[3] Ding, L. Z. (2005): Islanding landscape in thousand-island lake region and its effect on plant diversity. - Hangzhou, Zhejiang University.

[4] Ducatez, S., Shine, R. (2017): Drivers of extinction risk in terrestrial vertebrates. Conserv. Lett. 10: 186-194.

[5] Echeverría, C., Newton, A. C., Lara, A., Benayas, J. M. R., Coomes, D. A. (2007): Impacts of forest fragmentation on species composition and forest structure in the temperate landscape of southern Chile. - Global Ecol. Biogeogr. 16: 426-439.

[6] Fahrig, L., Girard, J., Duro, D., Pasher, J., Smith, A., Javorek, S., King, D. J., Lindsay, K. E., Mitchell, S. W., Tischendorf, L. (2015): Farmlands with smaller crop fields have higher within-field biodiversity. - Agric. Ecosyst. Environ. 200: 219-234.

[7] Giladi, I., May, F., Ristow, M., Jeltsch, F., Ziv, Y., Triantis, K. (2014): Scale-dependent species-area and species-isolation relationships: a review and a test study from a fragmented semi-arid agro-ecosystem. - J. Biogeogr. 41: 1055-1069.

[8] Haila, Y. (2002): A conceptual genealogy of fragmentation research: From island biogeography to landscape ecology. - Ecol Appl 12: 321-334.

[9] Halley, J. M., Sgardeli, V., Triantis, K. A. (2014): Extinction debt and the species-area relationship: a neutral perspective. - Global Ecol. Biogeogr. 23: 113-123.

[10] Hambäck, P. A., Summerville, K. S., Steffan-Dewenter, I., Krauss, J., Englund, G., Crist, T. (2007): Habitat specialization, body size, and family identity explain lepidopteran density-area relationships in a cross-continental comparison. - Proc. Natl Acad. Sci. USA. 104: 8368-8373.

[11] Hill, J. L., Curran, P. L. (2003): Area, shape and isolation of tropical forest fragments: effects on tree species diversity and implications for conservation. - J Biogeogr 30: 13911403.

[12] Hudson, L. N., Newbold, T., Contu, S., Hill, S., Lysenko, I., Palma, A. D., Phillips, H. R. P., Alhusseini, T. I., Bennett, D. J., Bugter, R. J. F., Buscardo, E. (2017): The database of the PREDICTS (Projecting Responses of Ecological Diversity in Changing Terrestrial Systems) project. - Ecol. Evol. 7: 145-188.

[13] Kolb, A., Diekmann, M. (2005): Effects of life-history traits on responses of plant species to forest fragmentation. - Conserv Biol 19: 929-938.

[14] Kornera, K., Jeltschb, F. (2008): Detecting general plant functional type responses in fragmented landscapes using spatially-explicit simulations. - Ecol. Model. 210: 287-300.

[15] Leal, I. R., Filgueiras, B. K., Gomes, J. P., Luciana, B., Bullet, I., Andersen, A. N., Conserv, B. (2012): Effects of habitat fragmentation on ant richness and functional composition in Brazilian Atlantic forest. - Biodivers. Conserv. 21(7): 1687-1701.

[16] Li, L. (2005): Study on germination and growth of Lespedeza davurica. - Changchun. Dongbei Normal University.

[17] Li, X. H., Li, X. L., Jiang, D. M., Liu, Z. M. (2006): Germination strategy and ecological adaptability of Eragrostis pilosa. - J Appl Ecol 17(4): 607-670. (in Chinese with English abstract).

[18] Liu, B., Liu, Z. M., Guan, D. X. (2008): Seedling growth variation in response to sand burial in four Artemisia species from different habitats in the semi-arid dune field. Trees-struct Funct 22: 41-47.

[19] Liu, J. G., Ouyang, Z. Y., Pimm, S. L. (2003): Protecting China's Biodiversity. - Science, 300: 1240-1241.

[20] Liu, Z. M., Yan, Q. L., Baskin, C. C., Ma, J. L. (2006): Burial of canopy-stored seeds in the annual psammophyte Agriophyllum squarrosum (Chenopodiaceae) and its ecological significance. - Plant Soil 288: 71-80. 
[21] Liu, Z. M., Li, X. L., Yan, Q. L., Wu, J. G. (2007): Species richness and vegetation pattern in interdune lowlands of an active dune field in Inner Mongolia, China. - Biol Conserv. 140: 29-39.

[22] Ma, J. L., Liu, Z. M., Zeng, D. H., Liu, B. (2010): Aerial seed bank in Artemisia species: how it responds to sand mobility. - Trees-struct Funct 24: 435-441.

[23] Matthews, T. J., Cottee-Jones, H. E. W., Whittaker, R. J. (2014): Habitat fragmentation and the species-area relationship: a focus on total species richness obscures the impact of habitat loss on habitat specialists. - Divers. Distrib. 20: 1136-1146.

[24] Murphy, G. E. P., Romanuk, T. N. (2014): A meta-analysis of declines in local species richness from human disturbances. - Ecol. Evol. 4: 91-103.

[25] Phillips, H. R. P., Halley, J. M., Urbina-Cardona, J. N., Purvis, A. (2018): The effect of fragment area on site-level biodiversity. - Ecography. 41: 1220-1231.

[26] Santos, B. A., Peres, C. A., Oliveira, M. A. (2008): Drastic erosion in functional attributes of tree assemblages in Atlantic forest fragments of northeastern Brazil. - Biol Conserv 141: 249-260.

[27] Swihart, R. K., Gehring, T. M., Kolozsvary, M. B. (2003): Responses of 'resistant' vertebrates to habitat loss and fragmentation: The importance of niche breadth and range boundaries. - Divers Distrib 9: 1-18.

[28] Winfree, R., Fox, J., Reilly, J. R., Carveau, D. P. (2015): Abundance of common species, not species richness, drives delivery of a real-world ecosystem service. - Ecol. Lett. 18: 626-635.

[29] Wu, J., Liu, Z. M., Qian, J. Q. (2013): Non-linear effect of habitat fragmentation on plant diversity: Evidence from a sand dune field in a desertified grassland in northeastern China. - Ecol Eng 54: 90-96.

[30] Wu, J., Qian, J. Q., Hou, X. Z., Carlos, A. B., Liu, Z. M., Xing, B. Z. (2016): Spatial variation of plant species richness in a sand dune field of northeastern Inner Mongolia,China. - J Arid Land 8: 434-442.

[31] Zobel, M., Moora, M., Herben, T. (2010): Clonal mobility and its implication for spatiotemporal patterns of plant communities: what do we need to know next? - Oikos 119: 802-806. 